\title{
IMPLEMENTASI MANAJEMEN BERBASIS SEKOLAH (MBS) DALAM MENINGKATKAN KOMPETENSI GURU DI SD NEGERI KALISARI II/513 SURABAYA
}

\author{
Sri Lestari \\ SD Negeri Kalisari II/513 Surabaya \\ gelis.srilestari@gmail.com
}

\begin{abstract}
Abstrak:
Dari pengamatan penulis, kompetensi guru perlu dibenahi sesuai dengan yang diinginkan, penulis ingin melakukan penelitian dengan rumusan masalah: "bagaimanakah implementasi manajemen berbasis sekolah dalam meningkatkan kompetensi guru di SD Negeri Kalisari II/513 Surabaya". Metode yang dipakai dalam penelitian adalah metode kualitatif dengan pendekatan deskriptif. Hasil yang diperoleh : Kepala sekolah melakukan diskusi untuk pengambilan kebijakan yang akan diterapkan oleh sekolah. Kompetensi Dasar (KD) dikembangkan sesuai dengan kemampuan siswa, guru menggunakan berbagai media pembelajaran yang terdiri dari media gambar, media langsung, media dengan menggunakan power point dan media yang selalu digunakan adalah media langsung, siswa-siswa memiliki peningkatan prestasi belajar dan menghadirkan kebahagian, serta kebanggan dihati guru terhadap prestasi yang dicapai oleh siswa dan terlihat peningkatan profesionalisme guru melalui implementasi Manajemen Berbasis Sekolah (MBS).
\end{abstract}

Kata Kunci: Manajemen Berbasis Sekolah, Kompetensi Guru

\begin{abstract}
From the author's observation, teacher competence needs to be addressed according to what is desired, the author wants to do research with the formulation of the problem: "how is the implementation of school-based management in improving teacher competency in SD Negeri Kalisari II / 513 Surabaya". The method used in the study is a qualitative method with a descriptive approach. Results obtained: The school principal conducts discussions for the policy-making that will be applied by the school. Basic competency (KD) was developed according to the ability of students, the teacher used a variety of learning media consisting of picture media, direct media, media using power point and the media that is always used is direct media, students have increased learning achievement and happiness presenting, and the pride of the heart of the teacher towards the achievements achieved by students and seen the increase in teacher professionalism through the implementation of School-Based Management (SBM).
\end{abstract}

Keywords: School Based Management, Teacher Competence 


\section{Pendahuluan}

Manajemen berbasis sekolah adalah model manajemen yang berasal dari tiga kata yakni: manajemen, berbasis, dan sekolah. Yang memili makna, manajemen merupakan "penyerasian sumber daya dengan menggunakan beberapa input manajemen untuk memenuhi kebutuhan manusia, kedua, merupakan dasar, sedangkan ketiga, sekolah yaitu sebuah organisasi di dalam jajaran pendidikan nasional yang bertugas dalam memberikan 'kemampuan dasar' kepada siswa dengan ketentuan-ketentuan yang bersifat legal dan professional ${ }^{1}$

Manajemen Berbasis Sekolah (MBS). Manajemen Berbasis Sekolah (MBS) memberikan otonomi kepada sekolah untuk menentukan kebijakan sekolah dalam meningkatkan mutu pendidikan. Manajemen Berbasis Sekolah (MBS) mempunyai tujuan utama sesuai dengan yang dikemukakan oleh Suryosubroto ${ }^{2}$, sebagai berikut: 1 . Mensosialisasikan konsep dasar manajemen pendidikan mutu berbasis sekolah khususnya kepada masyarakat; 2. Mendapatkan masukan agar konsep manajemen bisa dilaksanakan dengan mudah sesuai dengan kondisi lingkungan Indonesia yang memiliki keragaman kultural; 3. Menambah wawasan pengetahuan masyarakat sekolah dan individu yang peduli terhadap pendidikan khususnya peningkatan mutu pendidikan; 4. Memotivasi masyarakat sekolah untuk terlihat berpikir mengenai peningkatan mutu pendidikan; dan 5. Menggali kesadaran di dalam lingkungan sekolah agar turut serta secara aktif dan dinamis dalam mensukseskan peningkatan mutu pendidikan.

Berdasarkan pernyataan tersebut, sekolah diberi kewenangan yang lebih besar untuk mengelola pendidikan sesuai dengan potensi dan kebutuhan sekolahnya. Sekolah diberi keleluasaan untuk mengelola sumber daya yang ada sehingga dituntut kemandirian dan kreativitas dari sekolah dalam mengelola pendidikan. Disamping itu, sekolah menjalin kerjasama yang erat dengan masyarakat dan pemerintah sehingga sekolah dituntut memiliki tanggungjawab yang besar.

Adanya manajemen berbasis sekolah, diharapkan dapat menghasilkan guru yang kompeten sesuai dengan tujuan pendidikan nasional dan relevan dengan tuntutan perkembangan dalam masyarakat. Diterapkannya, Manajemen Berbasis Sekolah (MBS) diharapkan permasalahan-permasalahan terkait pendidikan di sekolah dapat terselesaikan ${ }^{3}$.

Kenyataannya, menurut pengamatan penulis kompetensi guru perlu dibenahi sesuai dengan yang diinginkan. Hal-hal yang tidak boleh terjadi di sekolah seperti adanya guru yang terlambat masuk mengajar, tidak mempunyai perangkat pembelajaran yang lengkap, tidak memiliki media pembelajaran sebagai alat menjelaskan materi pembelajaran, kurangnya koordinasi antar kepala sekolah dan guru, kepala sekolah kurang memberikan penghargaan bagi guru yang profesional. Kinerja guru akan baik apabila guru melakukan unsur-unsur yang terdiri dari kesetiaan dan komitmen yang tinggi pada tugas mengajar, menguasai, dan mengembangkan bahan pelajaran, kedisiplinan dalam mengajar dan tugas lainnya,

\footnotetext{
1 Slamet PH, Manajemen Berbasis Sekolah dalam Jurnal Pendidikan dan Kebudayaan, Balitbang Depdiknas, (Jakarta: November-2000), 609.

2 Asmani. Tips Aplikasi Manajemen Sekolah, (Jogjakarta: Diva Press. 2012), 21

3 Ibrahim, Bafadal. Manajemen Peningkatan Mutu Sekolah Dasar. (Jakarta: Bumi Aksara, 2012), 46
} 
Kreatifitas dalam pelaksanaan pengajaran, kerja sama dengan semua warga sekolah, kepemimpinan yang menjadi panutan peserta didik, kepribadian yang baik, jujur, objektif dalam membimbing peserta didik, serta tanggungjawab terhadap tugasnya ${ }^{4}$

Dari pemikiran di atas, penulis ingin melakukan penelitian dalam jurnal ilmiah ini dengan judul Implementasi Manajemen Berbasis Sekolah (MBS) dalam Meningkatkan Kompetensi Guru di SD Negeri Kalisari II/513 Surabaya

Rumusan masalah di dalam penelitian ini, yaitu: "Bagaimanakah implementasi manajemen berbasis sekolah dalam meningkatkan kompetensi guru SD Negeri Kalisari II/513 Surabaya". Tujuan penelitian yaitu: "Untuk mengetahui implementasi manajemen berbasis sekolah dalam meningkatkan kompetensi guru SD Negeri Kalisari II/513 Surabaya".

\section{Metode Penelitian}

\section{Jenis dan Pendekatan Penelitian}

Penelitian ini menggunakan pendekatan kualitatif dengan jenis penelitian deskripif. Penelitian ini dilaksanakan di SD Negeri Kalisari II/513 Surabaya Jalan Taman Bhaskara nomor 1, Desa/Kelurahan Kalisari, Kecamatan Mulyorejo, Kotamadya Surabaya, Propinsi Jawa Timur. Kode pos 60112. Nomor NPSN : 20564059, status : Negeri, bentuk pendidikan : SD, status kepemilikan : Pemerintah Daerah.

Subjek penelitian ini adalah guru SD Negeri Kalisari II/513 Surabaya sebanyak 17 guru, terdiri dari 5 guru laki, dan 12 guru perempuan, dengan jenjang pendidikan S1 sebanyak 15 guru, dan 2 guru berpendidikan S2. Teknik pengambilan sampel menggunakan sampling purposive ${ }^{5}$. Teknik pengumpulan data dengan observasi dan wawancara. Data yang telah terkumpul kemudian dianalisis dengan tahapan analisis data kualitatif, yaitu reduksi dat, display data, dan verifikasi data.

\section{Hasil Penelitian dan Pembahasan}

Implementasi Manajemen Berbasis Sekolah (MBS) dilihat melalui proses perencanaan kegiatan atau penyusunan program sekolah dengan melibatkan unsur guru-guru dan masyarakat akan mendorong terwujudnya keterbukaan dan akan menekan seminim mungkin tingkat kesalahan perencanaan. Kegiatan yang dilakukan oleh kepala sekolah tersebut sesuai dengan teori yang dikemukakan oleh Wahyusumidjo (2006), yang mengemukakan bahwa salah satu peran kepala sekolah memiliki banyak fungsi antara lain sebagai berikut: Sebagai manajer maka kepala sekolah harus memerankan fungsi manajerial dengan melakukan proses perencanaan, pengorganisasian, menggerakkan dan mengoordinasikan (planning, organizing, actuating, dan controlling). Merencanakan berkaitan dengan menetapkan tujuan dan strategi untuk mencapai tujuan tersebut. Mengorganisasian berkaitan dengan mendesain dan membuat struktur organisasi. Termasuk dalam hal ini adalah memilih orang-orang yang kompeten dalam menjalankan pekerjaan dan mencari sumber-sumber daya pendukung yang paling sesuai. Menggerakkan adalah mempengaruhi orang lain agar bersedia menjalankan tugasnya secara sukarela dalam rangka mencapai tujuan yang diinginkan. Mengontrol adalah

\footnotetext{
4 Suparlan. Manajemen Berbasis Sekolah. (Jakarta: Bumi Aksara, 2014), 46

5 Sugiyono. Metodelogi Penelitian. (Jakarta: RinekaCipta, 2010), 57
} 
membandingkan apakah yang dilaksanakan telah sesuai dengan yang direncanakan.

Kegiatan perencanaan dilaksanakan dengan matang dan dimusyawarahkan secara terbuka dengan melibatkan semua unsur-unsur, yaitu: Kepala Sekolah, Guru dan wali murid yang terdiri dari Proses penyusunan program tersebut memiliki tujuan utama untuk dapat mewujudkan visi, misi, dan tujuan sekolah.

Dalam pelaksanaan program Manajemen Berbasis Sekolah (MBS) yang bertujuan untuk meningkatkan profesionalisme guru. Menurut Direktorat Jenderal Pendidikian Dasar dan Menengah ${ }^{6}$, Manajemen Berbasis Sekolah (MBS) bertujuan untuk memandirikan dan memberdayakan sekolah melalui pemberian wewenang, keluwesan, dan sumber daya untuk meningkatkan mutu sekolah. Dengan demikian tujuan pelaksanaan Manajemen Berbasis Sekolah (MBS) yaitu untuk meningkatkan kualitas pendidikan secara umum baik itu menyangkut kualitas pembelajaran, kualitas kurikulum, kualitas sumber daya manusia baik guru maupun tenaga kependidikan lainnya, dan kualitas pelayanan pendidikan secara umum. Bagi sumber daya manusia, peningkatan kualitas bukan hanya meningkatnya pengetahuan dan keterampilannya, melainkan meningkatkan kesejahteraanya pula ${ }^{7}$.

Kompetensi guru dapat dilihat dalam pelaksanaannya, tanggungjawab guru tidak hanya terbatas pada proses dalam pentransferan ilmu pengetahuan. berbagai hal yang telah menjadi tanggungjawab profesi guru, yaitu salah satunya adalah memiliki kompetensi idealnya sebagaimana guru profesional. Kompetensi tersebut melingkupi pengetahuan, dan keterampilan profesional, baik yang bersifat pribadi, sosial, sikap, maupun akademis. Dengan kata lain, guru yang professional ini memiliki keahlian khusus dalam bidang keguruan sehingga mampu melaksanakan tugasnya secara maksimal dan terarah.

Dari hasil wawancara dengan beberapa guru, salah satu guru mengungkapkan hal sebagai berikut:

"Pelaksanaan manajemen berbasis sekolah mengedepankan perencanaan dengan melakukan analisis kebutuhan, dengan mampu melihat kebutuhan maka dapat diketahui hal-hal yang dijadikan tujuan yang selanjutnya dilakukan penyusunan perencanaan yang tepat."

Dalam pelaksanaan kegiatan belajar, seorang guru profesional harus terlebih dahulu mampu merencanakan program pengajaran. Kemudian melaksanakan program pengajaran dengan baik dan mengevaluasi hasil pembelajaran sehingga mampu mencapai tujuan pembelajaran ${ }^{8}$. Selain itu, seorang guru professional akan menghasilkan anak didik yang mampu menguasai pengetahuan baik dalam aspek kognitif, afektif, serta psikomotorik. Dengan demikian, seorang guru dikatakan professional apabila mampu menciptakan proses belajar mengajar yang berkualitas dan mendatangkan prestasi belajar yang baik. Demikian pula dengan siswa, baru dikatakan memiliki prestasi belajar yang maksimal apabila telah menguasai materi pelajaran dengan baik dan mampu

\footnotetext{
${ }^{6}$ E. Mulyasa, Manajemen Berbasis Sekolah. (Jakarta: Remaja Rosda Karya, 2011), 152

${ }^{7}$ Suryosubroto. Manajemen Pendidikan Sekolah. (Jakarta: Rineka Cipta).

8 Kunandar. Guru Profesional Implementasi Tingkat Satuan Pendidikan (KTSP) dan Sukses dalam Sertifikasi Guru. (Jakarta: Raja Grafindo Persada. 2010), 241
} 
mengaktualisasikannya. Prestasi itu akan terlihat berupa pengetahuan, sikap dan perbuatan. Kehadiran guru professional tentunya akan berakibat positif terhadap perkembangan siswa, baik dalam pengetahuan maupun dalam keterampilan. Oleh sebab itu, siswa akan antusias dengan apa yang disampaikan oleh guru yang bertindak sebagai fasilitator dalam proses kegiatan belajar mengajar. Bila hal itu terlaksana dengan baik, maka apa yang disampaikan oleh guru akan berpengaruh terhadap kemampuan atau prestasi belajar anak. Karena, disadari atau pun tidak, bahwa guru adalah factor eksternal dalam kegiatan pembelajaran yang sangat besar pengaruhnya terhadap keberhasilan proses kegiatan pembelajaran itu. Salah satu kunci keberhasilan berdasarkan informasi dari informan di sekolah dasar negeri kalisari II/513 sebagai berikut;

"Dalam melaksanakan MBS yang bertujuan meningkatkan hasil belajar siswa di sekolah dasar negeri kalisari II/513 Surabaya, kerjasama guru dan staf mutlak diperlukan untuk saling mendukung. Selama proses berlangsung maka dapat diketahui tingkat keberhasilan program yang diselenggarakan serta dapat dengan mudah mengetahui hal-hal yang perlu diperbaiki"

Untuk itu, kualitas guru akan memberikan pengaruh yang sangat berarti terhadap proses pembentukan prestasi anak didik ${ }^{9}$. Oleh karena itu, dengan keberadaan seorang guru professional diharapkan akan mampu memberikan pengaruh positif terhadap kelancaran dan keberhasilan proses belajar mengajar serta mampu memaksimalkan prestasi belajar siswa dengan sebaik-baiknya. Sehingga dapat disimpulkan dari wawancara kepada guru-guru, yaitu: kepala sekolah melakukan diskusi untuk pengambilan kebijakan yang akan diterapkan oleh sekolah, kepala sekolah melakukan diskusi dengan meminta saran dan pendapat guru untuk pengambilan kebijakan yang akan diterapkan oleh sekolah, kepala sekolah melakukan evaluasi dengan memeriksa perangkat pembelajaran, kehadiran guru, prestasi belajar siswa, dan keaktifan pada Kelompok Kerja Guru (KKG) yang dilakukan di setiap gugus. Dari berbagai wawancara dengan 10 guru, dapat disimpulkan kepala sekolah menciptakan lingkungan dan iklim kerja dengan memberikan kenyamanan di sekolah melalui hubungan yang baik antara guru dan kepala sekolah serta seluruh warga sekolah, serta menyelesaikan masalah yang terjadi serta memberikan jam ngajar yang sepantasnya, meminta seluruh warga sekolah untuk menjaga kebersihan dan saling menghargai antara guru dan teman sejawat. Prestasi kelulusan siswa setiap tahunnya mencapai 100\% lulus, ini membuktikan prestasi sekolah yang diperoleh melalui keberhasilan siswa, guruguru memanfaatkan waktu dengan sebaik-baiknya melalui proses pembelajaran sehingga dapat menghasilkan siswa yang baik. Kompetensi dasar dikembangkan sesuai dengan kemampuan siswa, guru menggunakan berbagai media pembelajaran yang terdiri dari media gambar, media langsung, media dengan menggunakan power point dan media yang selalu digunakan adalah media langsung, guru-guru memiliki peningkatan prestasi belajar dan menghadirkan kebahagian serta kebanggaan dihati guru terhadap prestasi yang dicapai oleh siswa.

\footnotetext{
${ }_{9}^{9}$ Udin Syaefududin Saud. Pengembangan Profesi Guru. (Bandung: Alfabeta, 2013), 121.
} 


\section{Penutup}

Kepala sekolah melakukan diskusi untuk pengambilan kebijakan yang akan diterapkan oleh sekolah, kepala sekolah melakukan diskusi dengan meminta saran dan pendapat guru untuk pengambilan kebijakan yang akan diterapkan oleh sekolah, kepala sekolah melakukan evaluasi dengan memeriksa perangkat pembelajaran, kehadiran guru, prestasi belajar siswa dan keaktifan pada Kelompok Kerja Guru (KKG) yang dilakukan di setiap gugus.

Kepala sekolah menciptakan lingkungan dan iklim kerja dengan memberikan kenyamanan di sekolah melalui hubungan yang baik antara guru, kepala sekolah beserta seluruh warga sekolah menyelesaikan masalah yang terjadi dengan memberikan jam mengajar yang sepantasnya, meminta seluruh warga sekolah untuk menjaga kebersihan dan saling menghargai antara guru dan guru.

Prestasi kelulusan siswa setiap tahunnya mencapai 100\%. Kelulusan ini membuktikan prestasi sekolah yang diperoleh melalui keberhasilan siswa, guruguru memanfaatkan waktu dengan sebaik-baiknya melalui proses pembelajaran sehingga dapat menghasilkan siswa yang baik. Kompetensi Dasar (KD) dikembangkan sesuai dengan kemampuan siswa, guru menggunakan berbagai media pembelajaran yang terdiri dari media gambar, media langsung, media dengan menggunakan power point dan media yang selalu digunakan adalah media langsung, siswa-siswa memiliki peningkatan prestasi belajar dan menghadirkan kebahagian, serta kebanggan dihati guru terhadap prestasi yang dicapai oleh siswa dan terlihat peningkatan profesionalisme guru melalui implementasi Manajemen Berbasis Sekolah (MBS).

\section{Daftar Pustaka}

Asmani. Tips Aplikasi Manajemen Sekolah, (Jogjakarta: Diva Press. 2012)

Bafadal, Ibrahim. Manajemen Peningkatan Mutu Sekolah Dasar. (Jakarta: Bumi Aksara, 2012)

Kunandar. Guru Profesional Implementasi Tingkat Satuan Pendidikan (KTSP) dan Sukses dalam Sertifikasi Guru. (Jakarta: Raja Grafindo Persada. 2010)

Mulyasa, E. Manajemen Berbasis Sekolah. (Jakarta: Remaja Rosda Karya, 2011)

Saud. Udin Syaefududin. Pengembangan Profesi Guru. (Bandung: Alfabeta, 2013)

Slamet PH, Manajemen Berbasis Sekolah dalam Jurnal Pendidikan dan Kebudayaan, Balitbang Depdiknas, (Jakarta: November-2000)

Sugiyono. Metodelogi Penelitian. (Jakarta: RinekaCipta, 2010)

Suparlan. Manajemen Berbasis Sekolah. (Jakarta: Bumi Aksara, 2014)

Suryosubroto. Manajemen Pendidikan Sekolah. (Jakarta: Rineka Cipta, 2004). 